\title{
Technical-Economic Prefeasibility Assessment of an off-grid Mini-Hydro Power Plant for an Agribusiness Resort in Kaduna Nigeria
}

\author{
${ }^{1^{*}}$ ADAMU Victor, ${ }^{1}$ AMPOFO Nana, ${ }^{1}$ PRAMONO JATI Ario Panggi, \\ ${ }^{1}$ TULABING Ryan, ${ }^{2}$ ROJAS-SOLORZANO Luis \\ ${ }^{1}$ Ecole des Mines de Nantes, Graduate School of Engineering, PM3E/ME3 \\ La Chantrerie - 4, rue Alfred Kastler - BP 20722, Nantes, 44307, France \\ ${ }^{2}$ Nazarbayev University, Department of Mechanical Engineering, Astana, 010000, Kazakhstan \\ *E-mail: vkadamu@yahoo.com
}

Keywords: Mini-hydro, pre-feasibility, clean energy, green-house-gas, economic, Nigeria

\begin{abstract}
Clean energy technologies are beginning to receive attention in Nigeria to offset the increasing greenhouse gas emissions. These emissions are associated to the wide use of small-scale fossil-fuel-powered generators by about $55 \%$ of its 180 -million people yet to be connected to the grid. While a large hydropower potential exists in Nigeria, even above the total electricity demand of the country, by 2013 this technology only accounted for about $32 \%$ of the total installed generation capacity connected to the grid. Previous studies have limited results in terms of technical, economic and environmental evidences that can drive choices towards small hydro and other clean energy projects for users and technology providers in Nigeria. This study uses the RETScreen Software to analyse the technical, economic and environmental aspects of a proposed mini-hydro power plant on the Tuwan River, to supply part of the energy needs of Tuwan Agribusiness Resort (TAR) located in Madakiya district, a rural community in Kaduna State, Nigeria. The volumetric flow and gross head of the chosen river were measured and the power generation system design yielded a $21 \mathrm{~kW}$ power output, capable to partially offset the present use of diesel generators and achieve a $307.4 \mathrm{tCO}_{2}$ equivalent GHG emission reduction. The financial analysis showed an attractive Internal Rate of Return (IRR) of $68.1 \%$ and NPV of 568,178 USD (11\% discount rate), owing to the high potential of the project to attract grants and tax rebates, which were put into consideration in the financial analysis. This study is important for Tuwan Agribusiness Resort, an agribusiness service provision outfit with a potential to create over 1000 jobs when fully operational.
\end{abstract}

\section{Introduction}

Per capita consumption of electricity in Nigeria is currently estimated to be $149 \mathrm{kWh} /$ year, which is considered very low compared to $13,246 \mathrm{kWh} /$ year per capita electricity consumption in USA (The World Bank, 2015). This demonstrates low access to electricity, which is a consequence of poor electricity generation and supply. This has led to an extensive use of diesel or gasoline operated generating set for electricity generation for industrial and commercial activities. Tuwan Agribusiness Resort (TAR) in Kaduna State, Nigeria developed by Premier Agricultural Development (PAD) Ltd is an agricultural service provision center offering agricultural value chain development services to rural farmers. TAR has demonstration facilities that show various technologies in production and processing of crops and fish. The demonstration facility sits on a 12 hectare plot of land with a stream of water flowing across it. Requirements for electricity are: lighting and powering equipments in offices, animal feed production and storage warehouse, recreation spots, lodging facility and the fish fingerling production hatchery. This is currently being met by two $25 \mathrm{~kW}$ diesel generators, which increases the operational cost of running TAR beyond what is expected when electricity is accessed from the grid and makes the venture unprofitable in the long run in addition to the considerable negative environmental effects of associated high green-house-gas (GHG) emissions.
Initiatives similar to TAR are fundamental in Nigeria, where there is a need to support food production activities to enable reduction of hunger and poverty in the country, with about $70 \%$ of the population depending on agriculture for income (Osugiri, et al., 2012).

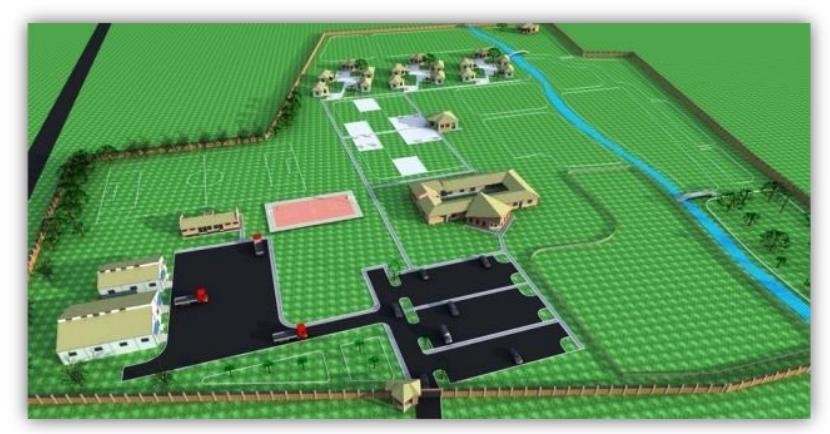

Fig. 1: Tuwan Agribusiness Resort conceptual design (PAD Ltd., 2012)

With booming energy demands from a growing population, one major household or business decision is the source of their energy supply, either by renewable sources, fossil fuels or a combination of both.

This study analyses, at prefeasibility level, the technical, economic, and environmental advantages of a proposed run-off river, mini-hydro power plant on the Tuwan River supplying part of the energy demand 
of TAR in comparison with supplying the full demand with two $25 \mathrm{~kW}$ diesel generators. This is a relevant project to the community since TAR, an agribusiness service provision outfit, is a social enterprise with a potential to stimulate the creation of over 1000 jobs when fully operational. The expected medium term outcome is the provision of a viable sustainable alternative to electricity supply for TAR, development of local capacity and community awareness on clean energy and sustainable development, while motivating research by local communities and tertiary institutions. In addition, it will serve as guide for other development agencies and small business owners investing in local communities in meeting their electricity needs beyond the classic choice of purchasing a diesel generating set (The Economist, 2010).

\section{Methodology}

The technical and financial analysis is mainly performed using the RETScreen software supported by extensive bibliographic review of relevant technology and financial information. Required technical input data are obtained through direct field measurements and from existing environmental and technical information databases online, as well as previously developed papers on the subject. Google Earth was also used for the topography study of the target site and to determine the gross head of the river with respect to the position of the hydropower turbine. It was fundamental to maintain close communication between the authors and international partners in Nigeria to obtain reliable onsite data.

\section{Results and discussions}

\section{II.1. Field Assessment}

The dimensioning of the hydropower plant is based on the net head and the water flow duration curve (Nasir, 2014). These are determined specifically from the physiographical and hydrological analysis, respectively, of data measured for at least 1 year. This is usually available from databases of the government or other private agencies.

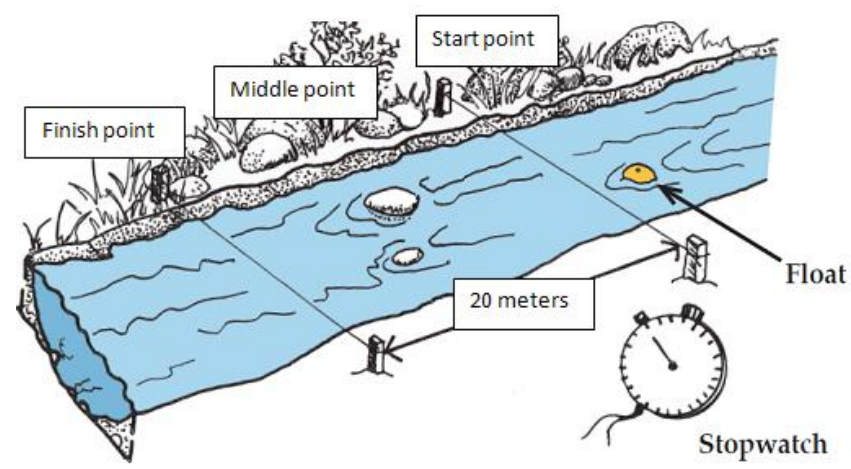

Fig. 2: Flow measurement by float method (Michaud, et al., 2005)

Climate and geological conditions are also needed to have a comprehensive perspective of the location. In the absence of data, in situ measurements can be made as in this case; for which flow measurements were made in collaboration with workers at the project site. The float method was used to measure the average volumetric flow rate of the river as shown in fig 2. This measurements were made in November 2014 and February 2015, during the dry season in Nigeria. Hence, the flow rate measured can safely be taken as the firm flow available 95 to $100 \%$ of the time since flow is expected to increase during the raining season. A $20 \mathrm{~m}$ length of relatively uniform stretch of the river was marked with 3 points: start, middle and end points. A float was made to travel between the two extreme points and the travel time was measured in order to determine the surface velocity $\left(\mathrm{V}_{\text {surface }}\right)$. To estimate the average crossectional area $\left(A_{\text {ave }}\right)$ of the river, the depth was measured at sections $0.5 \mathrm{~m}$ apart along the width of the river at the points marked as shown in fig. 3 .

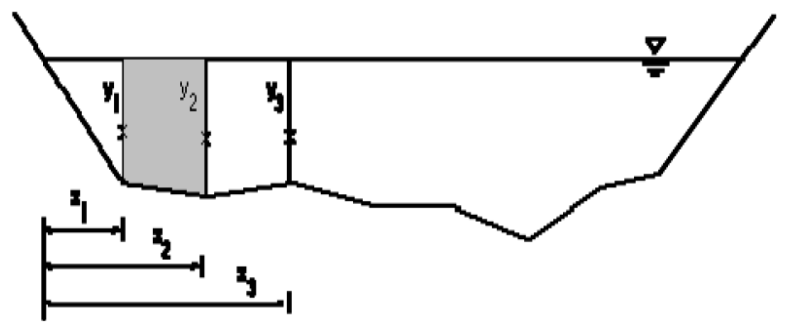

Fig. 3: Cross-sectional area measurement (Reckhow, et al., 2010)

The results of the measurement and the data used for the calulations are shown in Table 1.

Tab. 1: River flow measurement results

\begin{tabular}{|c|c|c|c|c|}
\hline \multirow{2}{*}{$\begin{array}{c}\text { Point } \\
\text { Width (m) }\end{array}$} & & Start & Mid & End \\
\hline & & 4.0 & 3.9 & 4.6 \\
\hline \multirow{8}{*}{$\begin{array}{l}\text { Depth across } \\
\text { stream width } \\
\text { (m) }\end{array}$} & $y 1$ & 0.58 & 0.63 & 0.25 \\
\hline & $y 2$ & 0.67 & 0.68 & 0.25 \\
\hline & y3 & 0.74 & 0.74 & 0.50 \\
\hline & $y 4$ & 0.80 & 0.72 & 0.63 \\
\hline & y5 & 0.83 & 0.62 & 0.59 \\
\hline & y6 & 0.83 & 0.48 & 0.45 \\
\hline & $y 7$ & 0.55 & 0.76 & 0.50 \\
\hline & $y 8$ & 0.76 & 0.34 & 0.23 \\
\hline \multirow{3}{*}{$\begin{array}{c}\text { Time of travel } \\
\text { (s) }\end{array}$} & Track 1 & \multicolumn{3}{|c|}{33.10} \\
\hline & Track 2 & \multicolumn{3}{|c|}{30.98} \\
\hline & Track 3 & \multicolumn{3}{|c|}{32.15} \\
\hline
\end{tabular}

From this method, $A_{\text {ave }}$ and $V_{\text {surface }}$ were determined to be $2.81 \mathrm{~m}^{2}$ and $0.62 \mathrm{~m} / \mathrm{s}$, respectively and used in eq. (1):

$$
Q=A_{\text {ave }} \times V_{\text {surface }} \times \text { Correction factor }
$$

The cross-sectional area was calculated as shown in fig. 4 below using measured data from the field.

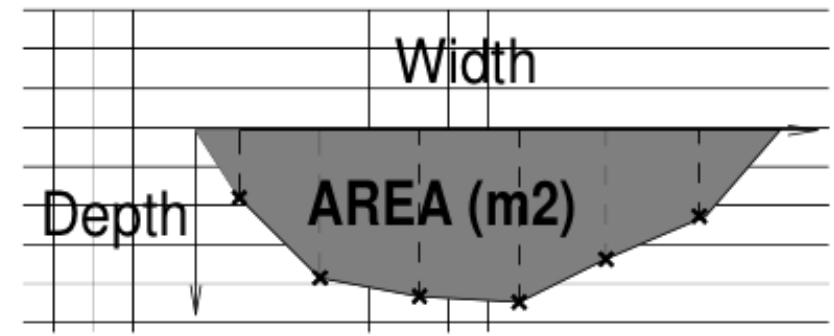

Fig. 4: Cross-sectional area calculation (Michaud, et al., 
2005)

Subsequently, the average flow (Q) of the river has been calculated as $1.2 \mathrm{~m}^{3} / \mathrm{s}$. The correction factor of 0.85 was used based on the characteristics of the river channel and bed (Hydromatch, 2014). This flow is considerably high in comparison to other similar small streams with flow rates in the range of $0.1-1 \mathrm{~m}^{3} / \mathrm{s}$ for widths in the range of $1-8 \mathrm{~m}$ (WHO, 1996). The flow rate was measured in November, a month characterized by draught based on the climatic and rainfall patterns of Nigeria. It is therefore sufficiently accurate at pre-feasibility phase to use this measured flow as the firm flow available $95 \%$ to $100 \%$ of the time in order to evaluate the power potential of the river. The residual flow has been assumed to be nil at this phase.

The land formation of the site is generally of gentle slopes. The approximate head available was determined via topographical applications of Google Earth to be $3 \mathrm{~m}$ over a distance of $321 \mathrm{~m}$. Although this value will generally be considered low head (Adhau et al., 2012), the relatively high flow compensates it in order to improve the general potential of the site.

The environmental impact of the project has been considered in terms of civil works. As a run-off-river of low power capacity, there is a need for the construction of a shallow reservoir, for water accumulation and channeling through a penstock. This will have minimum ecological modification impacts to the natural ambience. Nevertheless, an in-depth and compressive environmental impact assessment is mandatory as part of the feasibility study in the advanced stages of such a project.

\section{II.2. Technical Assessment}

With a $50 \mathrm{~kW}$ peak load from the Tuwan agribusiness off grid system, this Hydropower plant is designed to supply half of the load that is currently fully supplied with two $25 \mathrm{~kW}$ diesel generators. It is assumed that, the small hydropower plant runs all year round alongside one of the diesel generators to accommodate the entire electrical load at TAR while the second diesel generator is dropped as standby and only activated to take care of peak load conditions or emergencies.

This project is a run-off-river type considering a year round flow and the low initial cost since there is no need to construct a dam. With a low head, a Kaplan type turbine is selected for this system with the assumption that the flow will be at least $1.2 \mathrm{~m}^{3} / \mathrm{s}$ all year round. According to the RETScreen software "A conservative, rule-of-thumb relationship is that power from a hydro project is equal to seven times the product of the flow $(\mathrm{Q})$ and gross head $(\mathrm{H})$ at the site $(P=7 Q H)$." (RETScreen, 2004). The volumetric flow rate (Q) was calculated in the previous section to be 1.2 $\mathrm{m}^{3} / \mathrm{s}$ and a gross head of $3 \mathrm{~m}$ estimated over a distance of $321 \mathrm{~m}$. Thus, the estimated potential power from this site can be expressed as follows:

$$
\begin{aligned}
& \operatorname{Power}(k W) \approx 7 \times \operatorname{Head}(m) \times \operatorname{Flow}\left(\mathrm{m}^{3} / \mathrm{s}\right) \\
& \operatorname{Power}(k W) \approx 7 \times 3 m \times 1.2 \mathrm{~m}^{3} / \mathrm{s} \approx 25.2 \mathrm{~kW}
\end{aligned}
$$

By conducting a detailed Retscreen simulation, considering the hydraulic losses and generator efficiency, the expected power output from the generator is about $21 \mathrm{~kW}$. An AC direct electricity system is chosen for this Project. An asynchronous generator is used due to the consideration that this type of generator is suitable for isolated small hydropower of less than $100 \mathrm{~kW}$ installed capacity. It has several advantages, such as cheaper price compared to synchronous generators and ease of maintenance (Zhamalovich, et al., 2013). The electrical diagram for the system layout is presented in fig. 5 .

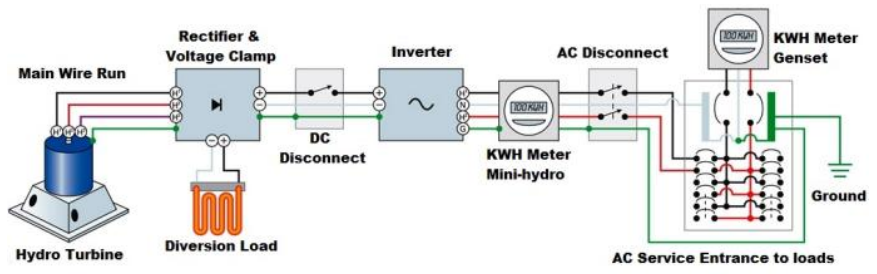

Fig. 5: Typical Arrangement of Electrical System in Mini Hydro Power Plant (Ostermeier, 2008)

As shown in the system layout, the output generator is connected to a rectifier and diversion load. This diversion load is used to consume any excess energy generated. It also protects the generator and inverter from over speed and overvoltage respectively. The DC system is then connected to the Inverter to provide the energy to the load with $220 \mathrm{VAC}, 50 \mathrm{~Hz}$.

\section{II.3. Cost and Financial Analysis}

The entire 20 year lifespan of the project is considered in the cost analysis. This is comprised of the initial cost, annual cost, and periodic cost. Table 2 provides the cost breakdown of the project.

\begin{tabular}{|c|c|c|}
\hline \multicolumn{3}{|c|}{ Project cost summary } \\
\hline \multicolumn{2}{|l|}{ Initial cost } & $100 \%$ \\
\hline Feasibility study & 5049.71 USD & $4 \%$ \\
\hline Development & 7441.67 USD & $6 \%$ \\
\hline Engineering & 15016.23 USD & $11 \%$ \\
\hline Power systems & 70430.11 USD & $53 \%$ \\
\hline Balance of systems \& misc. & 34949.28 USD & $26 \%$ \\
\hline \multicolumn{3}{|l|}{ Annual cost } \\
\hline Operation \& maintenance & 29260.00 USD & \\
\hline Debt payment & 7191.00 USD & \\
\hline \multicolumn{2}{|l|}{ Periodic cost } & \\
\hline $\begin{array}{r}\text { Inverter and parts replacement } \\
\text { every } 5 \text { years }\end{array}$ & 25000.00 USD & \\
\hline
\end{tabular}

Tab. 2: Project cost breakdown

The total initial cost prior to the operation phase of the project amounts to 132,887 USD which is based on the plant capacity and pricing of materials and labor in local and international standards. This breaks down to: feasibility study (3.8\%); development (5.6\%); engineering (11.3\%); power system (53\%); and balance of system and miscellaneous costs (26.3\%). The bulk of the initial cost is taken by the civil works, 
turbine, generator, and electrical system.

On the other hand, the annual cost in terms of operation, maintenance, and payment of debt terms (up to 5 years) sums up to 36,451 USD per year. Meanwhile, a periodic cost of 2,500 USD every 5 years is allotted for the replacement of inverters and other parts.

Fortunately, a projected grant of 50,000 USD that can be accessed from development funding partners of PAD Ltd should reduce the share of loan required to fund the project. Thus, the debt ratio is only $20 \%$, which means only 26,577 USD is to be borrowed from the bank to be paid in 5 years with $11 \%$ interest rate. Inflation is assumed to be $8.5 \%$ while the fuel escalation is $10 \%$ from its present value of 0.54 USD per liter as at year 2014. This project has a positive cash flow of 65,723 USD per year and a steadily increasing positive cashflows in the long run as seen in fig. 6 .

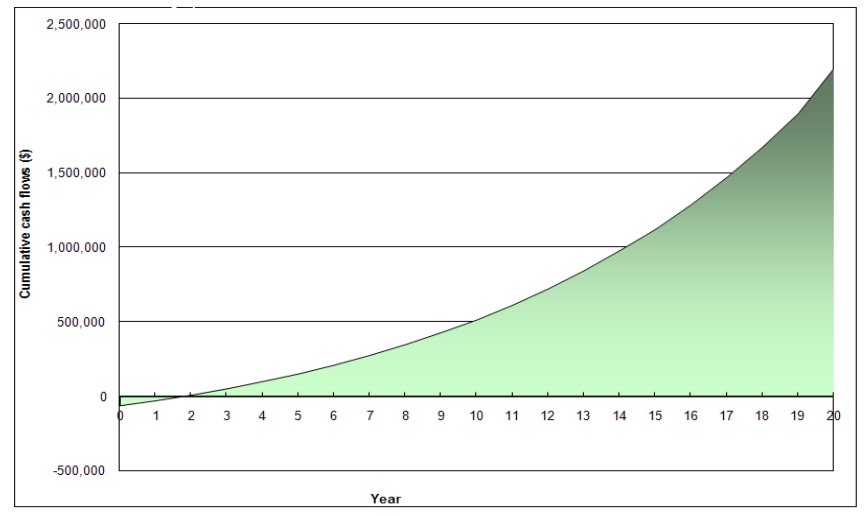

Fig. 6: Cumulative cash flow of the project in 20-year lifespan (RETScreen, 2004)

The income elements are mainly the amount of fuel savings and 15,000 USD salvage value of the system at the end of project lifespan as shown in Table 3.

Tab. 3: Summary of project income and savings

\begin{tabular}{|c|c|}
\hline \multicolumn{2}{|c|}{ Project income summary } \\
\hline Annual income & \\
\hline Periodic income & \\
\hline System salvage value after 20 years & 15000.00 USD \\
\hline
\end{tabular}

Aside from the grant, another positive factor is the tax holiday of 5 years (i.e. exception from $15 \%$ tax on income during the first 5 years of the project) granted by the government to agricultural organizations and rural infrastructural development (KPMG, 2012).

In summary, as indicated in Table 4, the project is viable with Net Present Value (NPV) of 568,178 USD ( $11 \%$ discount rate), Internal Rate of Return (IRR) of $68.1 \%$ and Benefit-Cost ratio of 6.34 .

Tab. 4: Summary of financial viability of the project Financial viability

\begin{tabular}{|l|r|}
\hline Pre-tax IRR-equity & $72.7 \%$ \\
\hline Pre-tax IRR-assets & $53.6 \%$ \\
\hline After-tax IRR- equity & $68.1 \%$ \\
\hline After-tax IRR- assets & $54.1 \%$ \\
\hline
\end{tabular}

\begin{tabular}{|l|r|}
\hline Simple payback & $2.3 \mathrm{yr}$ \\
\hline Equity payback & $1.7 \mathrm{yr}$ \\
\hline Net Present Value (NPV) & $568,178 \mathrm{USD}$ \\
\hline Annual life cycle savings & 71,349 USD \\
\hline Benefit-Cost (B-C) ratio & 6.34 \\
\hline Debt service coverage & 5.64 \\
\hline & \\
\hline
\end{tabular}

\section{II.4. Green house gas (GHG) emission}

According to UNIPCC compounds considered as GHG are carbon di-oxide $\left(\mathrm{CO}_{2}\right)$, methane $\left(\mathrm{CH}_{4}\right)$, Nitrous oxide $\left(\mathrm{N}_{2} \mathrm{O}\right)$, Ozone $\left(\mathrm{O}_{3}\right)$ and water vapor measured in units of $\mathrm{tCO}_{2}$ equivalent. The Kyoto protocol defines additional compounds of Sulphur hexafluoride $\left(\mathrm{SF}_{6}\right)$, hydroflourocarbons (HFCs) and perflourocarbons (PFCs) as green house gases. Diesel generators emit a number of these gases, mainly $\mathrm{CO}_{2}$ and water vapor. Considering the emission factor of diesel fuel of 0.2520 $\mathrm{tCO}_{2}$ per $\mathrm{MWh}$ and estimated energy of 1,221 $\mathrm{MWh} /$ year produced by the hydro power plant in place of the second diesel generator, the GHG emission avoided is a total of $307.4 \mathrm{tCO}_{2}$ equivalent per year. The hydropower plant has no GHG emission as it does not make use of fossil fuel. This GHG emission savings translate to 56 cars and light trucks off the road per year.

\section{II.5. Sensitivity and risk analysis}

The sensitivity analysis was performed on the Net Present Value (NPV), which is favorable to such a capital intensive project with long term profitability. A threshold of 200,000 USD and a sensitivity range of $20 \%$ show that varying the fuel cost and the debt interest rate against the initial project cost results in values all above the threshold. This means that the sensitive factors of fuel cost, initial cost, operation and maintenance cost and debt interest rate can not make the project unviable in the case that they change over the provided range. An increase in the fuel price and a reduction of initial cost, operating and maintenance costs and debt interest rate are favorable to the project analysis. The tornado diagram in Fig. 7 shows that an increase in the fuel cost (base case) and debt ratio will affect the project positively. On the other hand an increase in the operating and maintenance cost of the mini-hydro power plant, the initial costs of the project, debt term and debt interest rate will affect the project negatively.

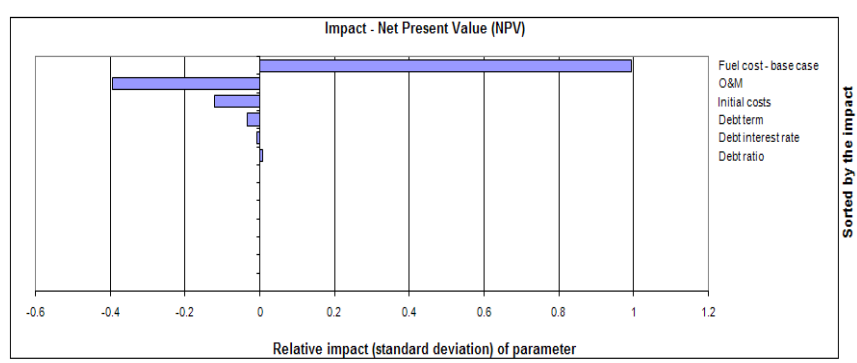

Fig. 7: Project sensitivity analysis (RETScreen, 2004)

At a conservative risk level of $10 \%(90 \%$ of confidence range) the project has a median NPV of 569,451 USD. 
The minimum and maximum confidence NPV values of 516,324 USD and 625,649 USD respectively, confirm that the project has $90 \%$ of likelihood to succeed in that range, which are indeed still very attractive values for the NPV. The histogram in fig. 8 shows that the $90 \%$ confidence region is much higher than the $10 \%$ risk region.

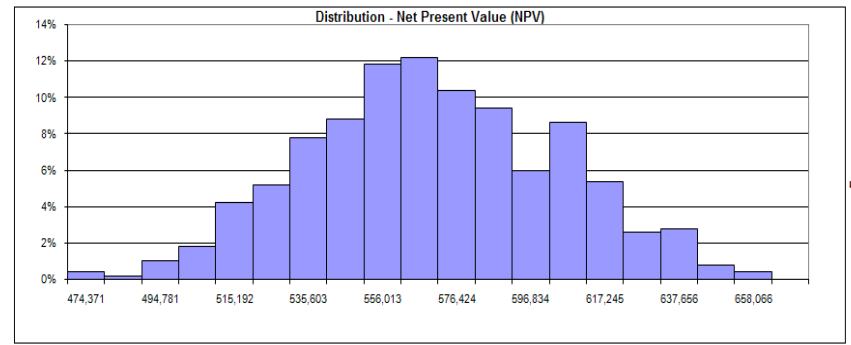

Fig. 8: Project risk analysis (RETScreen, 2004)

\section{Conclusions}

The potential of electricity generation by a small hydro power plant on Tuwan River which flows across TAR is presented by this project. In particular, the financial and GHG savings of the proposed case are compared to the full power supply using diesel gensets. The following conclusions are drawn from the analysis:

- According to local measurements Tuwan river may provide to this project an estimate of at least $21 \mathrm{~kW}$ power generation potential with a Kaplan turbine throughout the year;

- The hydropower project provides a GHG emissions reduction of $307.4 \mathrm{tCO}_{2}$ equivalent;

A Net Present Value (NPV) of 568,178 USD (11\% discount rate), Internal Rate of Return (IRR) of $68.1 \%$ and Benefit-Cost ratio of 6.34 with incentives of a 50,000 USD grant and a tax holiday are obtained in favour of the mini-hydropower plant.

The analysis shows that it is economically and environmentally attractive to pursue a mini-hydro project. Thus, it is safe to invest more funds to conduct an extensive feasibility study with the aim of convincing fund (grant and loan) providers to invest in the project.

\section{Acknowledgements}

This research was made possible with the support of ROJAS-SOLORZANO Luis, THERON Felicie of Ecole Nationale Superieure des Mines de Nantes. Premier Agricultural Development Ltd. provided the site and corresponding data and their staff carried out required field measurements.

\section{References}

Adhau, S. P., Moharil, R. M., \& Adhau, P. G. (2012). Mini-hydro power generation on existing irrigation projects: Case study of Indian sites. Renewable and Sustainable Energy Reviews, 16(7), 4785-4795. http://doi.org/10.1016/j.rser.2012.03.066
BPE. (2011). ELECTRIC POWER INVESTORS ' FORUM

by Bureau of Public Enterprises ( BPE ), Power

Generation, Nigeria. Retrieved from

http://www.nigeriaelectricityprivatisation.com/wp-cont ent/uploads/downloads/2011/02/Power_Generation_ Outlook Investor Forum Presentation BPE.pdf

Energy Commission, N. (2013). National Enērgy Policy.

Froend, O. (2012). Assessment of hydropower resources ( $p$. 39).

Hydromatch. (2014). Flow estimation for streams and small rivers Width Depth. Retrieved from

http://www.hydromatch.com/sites/default/files/downlo ads/DIY-flow-measurement-guide.pdf

International Energy Agency. (2013). World energy outlook Paris: International Energy Agency. Retrieved from http://vnk.fi/tiedostot/julkinen/talousneuvosto/muistiot/ TN-esitykset_14-04-07.pdf

KPMG. Nigeria Fiscal Guide Introduction : Nigeria Fiscal Guide 2011 (2011). Retrieved from http://www.kpmg.com/Africa/en/KPMG-in-Africa/Docu ments/MC9197_Fiscal Guide_Nigeria.pdf

Michaud, J. P., \& Wierenga, M. (2005). ESTIMATING DISCHARGE AND STREAM FLOWS A Guide for Sand and Gravel Operators. Retrieved from https://fortress.wa.gov/ecy/publications/publications/0 510070.pdf

Nasir, B. A. (2013). Design of Micro - Hydro - Electric Power Station. International Journal of Engineering and Advanced Technology (IJEAT), 2(5), 39-47.

Nnaji, B. (2011). FEDERAL REPUBLIC OF NIGERIA POWER SECTOR OUTLOOK IN NIGERIA: Governments Renewed Priorities.

Osigir, I. I., Ugochukwu, A. I., \& Onyemauwa, S. U. O. (2012). Population Dynamics , Labour and Small-Holder Farmers ' Productivity in Southeast Nigeria. Journal of Economics and Sustainable Development, 3(12), 95-101.

Ostermeier, J., \& Schwartz, J. (2008). The Electric Side of Hydro Power Power Transmission \& Regulation Considerations. Retrieved from http://www.homepower.com/articles/microhydro-powe r/design-installation/electric-side-hydro-power

Reckhow, D. A., Boning, L., \& Sheppard, D. (2010). Lab Exercise \# 1 : Stream flow Objective : (pp. 1-10). Retrieved from http://www.ecs.umass.edu/cee/reckhow/courses/370/ Lab1/Stream flow lab.pdf

RETScreen. (2004). RETScreen $\AA$ International CLEAN ENERGY PROJECT ANALYSIS :

SEC. (2014). The Nigeria Power Sector - 4 th Annual Capital Market Committee Retreat of the Securities \& Exchange Commission (SEC). Retrieved from http://www.cmcretreat.com.ng/presentations/2014/da y-3/the-nigeria-power-sector-by-prof-chinedu-nebo.pd $f$

The Economist. (2010). Electricity in Nigeria Let there be light. Retrieved from http://www.economist.com/node/17312103

The World Bank. (2014). Data - Access to Electricity (\% of Population). Retrieved from http://data.worldbank.org/indicator/EG.ELC.ACCS.ZS /countries/1W-NG?display=default

WHO/UNESCO/UNEP. (1996). Water Quality Assessments - A guide to use of biota, sediments and water in enviromental monitoring. Retrieved from http://www.who.int/water_sanitation_health/resources quality/watqualassess.pdf

Zhamalovich, A., Alaibek, Z., \& Obozov, D. (2013). Selection of Generator for the Micro Hydro Power Plant. American-Eurasian Journal of Scientific Research, 
8(3), 104-108.

http://doi.org/10.5829/idosi.aejsr.2013.8.3.1116 